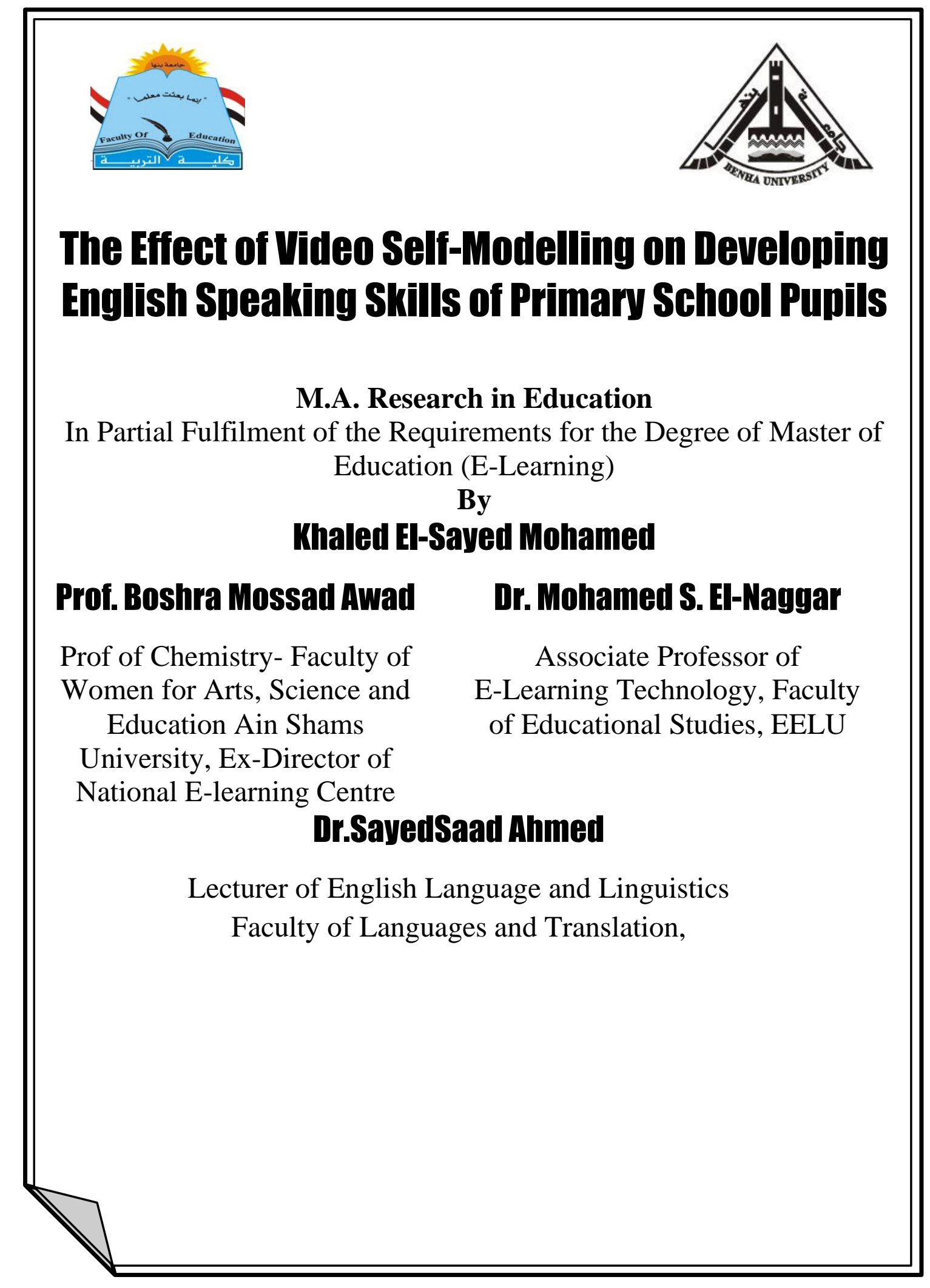




\title{
The Effect of Video Self-Modelling on Developing English Speaking Skills of Primary School Pupils
}

\begin{abstract}
The present study aimed to investigate the effect of video self-modelingon developing the English speaking skills of primary school pupils. The participants of the study were 4 pupils ( 3 girls and a boy) aged 10 . The four pupils were slow learners showing a low level in all English language speaking skills. One-group pretest-posttest design was applied. A pre- and post-test of speaking skills was administered to the participants before and after implementing the study intervention. They were filmed while responding to some speaking tasks and activities. After editing their videos, deleting errors hesitations, stops, and irrelevant responses, the researcher created 2 short videos for each pupil. Pupils watched their edited video three times a week for three weeks. Results indicated that VSM intervention had a positive effect on developing speaking skills of the study sample.
\end{abstract}

KEYWORDS: Video self-modeling, speaking skills, Primary school pupils,slow learners 


\section{Introduction:}

Speaking skills are the most important aspects of any language. In Egypt, English is taught as a foreign language and the main goal is communication. However, speaking is highly undervalued in the teaching and learning process in EFL classrooms in Egypt. The whole focus is on reading and writing skills. The result is that pupils do not communicate effectively. They cannot speak the language fluently.

Segura (2012, p.19) stated that speaking is an important language skill but at the same time, it is the most difficult skill for students to learn. Rizvi (2005, pp.14-15) indicated that speaking skills are the most important means to develop effective communication. Unfortunately, speaking does not occupy its priority inside the EFL classroom. Most of speaking tasks and activities are drilling and repetition

Diyyab (2014, p. 3) assured that nowadays there is more interest in teaching speaking skills because a lot of learners want to use English for communication. Previously speaking skills were thought to be acquired by teaching other skills of reading and writing without adopting certain strategies and activities for speaking as a challenging skill. Neglecting teaching speaking skills did not lead to the desired results of fluent and spontaneous speaking.

Regarding Egyptian students' perspectives about their English skills, a survey has been conducted by Mcllwraith and Fortune on 198 students who had ten or more years of learning English. Results showed that most of the students who participated in this survey believed that their speaking 
skills were low and they were less confident about their oral communication skills (Mcllwraith\& Fortune, 2016, p. 13).

Learning to speak our mother tongue language is mainly through the process of imitation and modeling. Children imitate their parents and gradually acquire language skills and start to utter simple words, phrases, and sentences. Observational learning theory explains how we acquire a language. This theory highlights the role of observation, imitation, and modeling in learning. Reinforcement is very important in maintaining desirable behaviors and skills. According to observational learning, our beliefs about our self-efficacy determine what we can achieve and learn.

This study adopted a technique called video self-modeling (VSM) in developing speaking skills. Dowrick (2012, p. 31) considered VSM a form of observational learning with the distinction that the observed and the observer, (object, and subject), are the same person. In VSM, the learner is filmed while speaking fluently and answering questions successfully, (with the help of his teacher). Later the learner watches his edited video showing his successful performance after eliminating teacher's support and undesirable responses. The learner keeps watching his edited successful performance videos for weeks.

\section{Context of the problem:}

Although speaking is the most important skill in any language, pupils after years of studying English language are not able to speak fluently or communicate using the target language. Speaking skills are undervalued in EFL classrooms. Thus, there is a real need to adopt new techniques to encourage our students to speak fluently and to overcome their fears of 
speaking English making use of modern technology progress in devices and applications.

There is a remarkable weakness in speaking skills in EFL of fourthyear primary school pupils. The researcher of the present study encountered this problem in different sources:

First, through the researcher's experience as a teacher of English, he noticed that pupils have poor speaking skills. They cannot express themselves and they also have problems in pronunciation, grammar, and vocabulary.

Second, a pilot study has been conducted on a fourth-year class in primary school (El-Sayed Nasr Primary School - KafrShukr Educational Directorate). Pupils were asked to answer some simple questions about their likes and to describe some pictures. Thirty-six pupils participated in the pilot study. The study showed that most of the pupils were not able to speak English. Only 37\% succeeded in this simple speaking test. Their fluency was very poor with a lot of hesitations, stuttering, shyness, low voices and a lot of them came with no utterance at all.

Third, the previous related studies that were reviewed revealed the existence of the problem of English language speaking among EFL learners in general, and among primary school pupils in particular like Torky, (2006), Amin, (2007), Ali, (2010), Lackman, (2010), Dorgham, (2011), Selim, (2011), Mcllwraith\& Fortune, (2016), Waly, (2017), and Ezz, (2018).

All previous consideration necessitated conducting the current study as an attempt to tackle the problem of primary pupils weakness in speaking 
using a modeling technique (video-self modeling), that enhances pupils' self-efficacy and encourage them to speak fluently and overcome their fears by modeling and imitating themselves while they are performing successfully in their edited videos.

\section{Statement of the Problem:}

The problem of the present study lies in that fourth-year primary pupils lack EFL speaking skills.

\section{Questions of the study:}

Thus the problem of this study can be formulated in the following question:

"What is the effect of video self-modeling on developing English speaking skills of primary school pupils?"

The main question is branched up into the subsequent questions as follows:

1. What are the English speaking skills required for primary school pupils?

2. What is VSM, its theoretical base, and types?

3. How far is VSM effective for developing the speaking skills of EFL of Primary School Pupils?

\section{Design:}

A quasi-experimental, one-group pretest-posttest design was used throughout this study.

Thyer (2012, p. 24) pointed out that one of the strengths of quasiexperimental design is that they are sufficiently flexible to be useful in 
the handling of many types of interventions, regardless of the theoretical basis of that treatment.

Cranmer (2017, pp. 1125-1126) stated that a one-group pre-testpost-test design is a type of research design that is most often applied by behavioral researchers to examine the effect of a treatment or intervention on a given sample. This research design includes two characteristics. The first one is the use of one and a single group of participants. This feature highlights that all members of the sample are part of a single condition-meaning that, the same treatment and intervention conditions are applied to study participants. The second characteristic is a linear ordering that requires examining the dependent variable of the study before and after implementing the study intervention. Within pre-test-post-test research designs, the impact of an intervention is determined by finding out the difference between the pre and post-test results.

There are many designs of quasi-experiments. After reviewing literature and related studies, the present study applied a single group, pre-and post-test research designs for two reasons. Firstly, most of the studies in this field use only the participants who receive the independent variable; not using a control group. Secondly, there is no teaching method in the intervention and all the material and tasks were only used for the sake of creating the videos that showed the pupil speaking fluently. Moreover, the materials were curriculum-based collected from the student textbook of fourth primary.

To investigate the effect of the independent variable (Video selfmodeling) on the dependent variable (speaking skills), four slow pupils 
from primary school fourth grade were randomly chosen from the lowest achievers in speaking pilot study done by the researcher. A prepost speaking skill test was administered to each pupil before applying the study intervention (video self-modeling). After administrating the pre-test, videos were created for each pupil and then edited to show their best performance. After Pupils had watched their edited videos, post-test was administrated to collect data about the effect of the study intervention

Pre-post-test one group design

\section{One-Group Pretest-Posttest}

Group

A

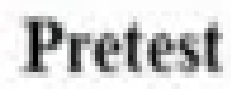

Intervention

\section{Time}

\section{Participants of the study}

The participants of the present study consisted of four slow pupils form grade four, primary governorate school, aged 10, including three girls and a boy.

\section{Hypotheses of the study:}

Hypothesis 1: There is a statistically significant difference at the 0.05 level between the mean ranks scores of the sample pupils' pre and post speaking skills test regarding sub-skills in favor of the post-test. 
Hypothesis 2: There is a statistically significant difference at the 0.05 level between the mean ranks scores of the sample pupils' pre and post speaking skills test regarding the overall test in favor of the post-test.

\section{Variables of the study}

Independent variable: Video-self-modeling

Dependent variable: the pupils' performance on the speaking test

\section{Limitations of the study}

The present study is limited to:

- applying VSM intervention (feed-forward type) with primary school fourth grade slow pupils.

- Four slow pupils from fourth grade, primary government school (El-Sayed Nasr Sarhan Primary School - Qalyubia Governorate).

- Selected speaking skills that are required forEFLprimary school fourth-year pupils.

- The second semester of the scholastic year 2019-2020

\section{Instrumentsand materials:}

The present study used the following instruments:

- A Speaking Skills Checklist

- A Speaking Test developed by the researcher used as pre-and posttest.

- A Rubric developed by the researcher to score students' performance on the pre-and post-test. 


\section{Purpose:}

The purpose of this study was to investigate the effect of video selfmodeling on developing the targeted English speaking sub-skills (in speaking skills checklist) of primary school pupils.

\section{Significance of the study:}

The significance of this study lies in the hypothesized possibility that implementing video-self-modeling will develop pupils' speaking skills, so the study can be beneficial for:

Pupils and their communication competence. By enhancing pupil's self-efficacy which is a major component of this study, they can make progress in language speaking skills and attain a high level of enthusiasm for learning in general.

Teachers of English as the study will provide them with a new technique they can adopt in teaching speaking skills. Teachers with this technique can help pupils overcome speaking and communication obstacles like shyness, anxiety, and hesitation.

\section{Definition of terms:}

\section{Speaking:}

Speaking is an interactive process of constructing meaning that involves producing and receiving and processing information. Its form and meaning are dependent on the context in which it occurs, including the participants themselves, their collective experiences, the physical environment, and the purposes for speaking (Florez, 1999, p. 2). 
Speaking is defined as the students' ability to express themselves orally, coherently, fluently and appropriately in a given meaningful context to serve both transactional and interactional purposed using correct pronunciation, grammar, and vocabulary and adopting the pragmatic and discourse rules of the spoken language (Torky, 2006, p. $30)$.

El-Bassuony (2010 p. 24) defined speaking as the ability to express oneself in any situation appropriately using verbal and non-verbal symbols to convey a specific meaning.

In the present study, speaking is operationally defined as the pupils' ability to utter words and sentences to espresso themselves using verbal and nonverbal skills.

\section{Speaking fluency:}

Fluency refers to speaking at a normal speed, without hesitation, repetition, or self-correction, and with smooth use of connected speech (Mary et al., 2005, p. 34).

Speaking fluency can be defined as the natural ability to speak spontaneously as quickly, smoothly, accurately, lucid, efficient and comprehensibly with few numbers of errors that may distract the listener from the speaker's message (Iswara et al., 2012, pp. 5-6).

In the present study, speaking fluency is operationally defined as pupils' ability to speak naturally with little hesitations. 


\section{Video Self-modeling:}

Video Self-modeling is an intervention procedure using the observation of images of oneself engaged in adaptive behavior. Most commonly, these images are captured on video, edited into 2-4 minute vignettes, and repeatedly reviewed to learn skills (Dowrick, 1999, p. 23).

Chappel (2008, p. 16) Video Self-Modeling (VSM) is an intervention in which observers are shown videotapes of themselves successfully engaging in an activity and performing well.

In the present study, VSM is defined operationally as the procedures in which pupils are filmed while responding to speaking tasks then, they watch their edited videos showing them speaking fluently without hesitations, stops or undesired responses to enhance some speaking skills and to increase their self-efficacy in speaking in general

\section{Slow learners (slow pupils):}

Borah (2013, p. 139) pointed out that slow learnersare not disabled but they are normal learners with low cognitive abilities.

According to Shmavonyan and Karapetyan (2017, p. 142) "slow learner" is a term that refers to a student who has limited intellectual abilities to learn specific academic skills, the one who learns more slowly than his/her peers.

In the present study, the term of slow pupils refers to pupils who got the lowest marks in class speaking quizzes of the first school semester and the pilot study speaking test. 


\section{Procedures of the Study:}

The following procedures were followed to carry out the present study:

a) Reviewing literature and previous studies related to EFL speaking skills.

b) Preparing a list of EFL speaking skills required for fourth primary pupils.

c) Submitting the list to a jury to verify its validity.

d) Modifying and setting the list in its final form according to the jury's suggestions.

e) Developing an EFL speaking fluency test to be used as a pre- and posttest, and submitting the test to a jury to verify its validity.

f) Modifying and setting the test in its final form according to the jury's suggestions.

g) Drawing the study sample of slow pupils from the fourth primary.

h) Applying the EFL speaking test to the study sample before conducting VSM intervention.

I) Collecting proper speaking tasks and activities from the fourth primary textbooks.

j) Arranging settings for applying the intervention.

k) Recording videos for each pupil.

1) Editing videos to create two short videos for each pupil showing him performing and speaking fluently without errors or hesitations. 
m) Getting pupils to watch their videos 3 times a week for three weeks.

n) Applying speaking post-test and collecting results.

o) Doing statistical analysis and finding out results and conclusions.

\section{Theoretical background and literature review}

\section{Speaking}

According to Florez $(1999$, p. 2), speaking is not uttering words but an interactive process that aims at conveying meaning. Speaking includes producing, receiving, and processing information. Language functions and patterns help in learning speaking and maintaining communication. However, speaking depends on the situations, participants, and the message being connived. All these factors provide a challenge to learning speaking.

Nazara (2011 p. 31) pointed out that speaking has many different interrelated aspects and this makes it difficult to find a comprehensive definition for speaking. We can deal with speaking as a spoken discourse that is not isolated but occurs in a social situation to convey a social purpose. Speaking is a specific spoken discourse that is primarily social and engaged in for social purposes and in social contexts

\section{Speaking skills:}

ŠOLCOVÁ (2012, p. 17) stated that speaking has often been narrowly defined. When speaking skills are discussed, this often happens in the context of public speaking. Speaking skills, however, are much more than that. Alternatively, a comprehensive definition focuses either on communication to achieve specific functions (e.g., to inform, to ask for 
directions, ...etc.) or describe the process of speaking in terms of its basic competence used in daily communication such as ordering a meal, giving advice, etc. These approaches deal with speaking and communication as a process of interaction between people. we exchange our roles as speakers and listeners to express ourselves and understand each other employing verbal and nonverbal means to achieve our communicative goals.

\section{Complexity of speaking skills:}

Zhang (2009, p. 32) explained why speaking skills are difficult. He found that in addition to being an important skill, speaking is also a great challenge for a foreign language learner. English language students have to master several difficult speaking micro-skills, including the pronunciation of words, correct stress and intonation, and formal and informal language. In the EFL learning situation, learning speaking becomes more difficult because most of the exposure to the target language is inside the classroom where there is a lack of real-life communication.

Kaminskiene andKavaliauskiene (2014, p. 39) assured that speaking is so complicated process that makes it difficult for pupils to use and master second language speaking skills. Similarly, Segura (2012, p. 22) explained why speaking is thought to be difficult for many learners as it requires not only words and phrases but mainly interaction with other people. This may be challenging for learners when they start to communicate because they have to understand not only the utterance of the speaker but also their facial expressions, body language, and gestures to communicate effectively.

\section{2}




\section{Types of speaking skills:}

In his book, Brown (2004, pp. 142-144) distinguished two typesofspeaking skills: micro and macro skills. They specify the different components of speaking and provide criteria for assessment. Teachers can select one or several of these skills to be the core of assessment activity. The micro-skills refer to uttering smaller chunks of language like phonemes, morphemes, words, and phrases.The macro skillsinvolve the speaker's larger discourse, functions, speaking strategies, and nonverbal communication.

\section{Micro skills:}

1. Use a variety of English phonemes forms.

2. Use different portions of language chunks.

3. Use correct intonation, rhythm, and stress patterns.

4. Use shortened forms of words and phrases.

5. Use a suitable number of lexical units (words)to accomplish real functions.

6. Produce spontaneous and fluent speech at a reasonable speaking rate

7. Use speaking various strategies such as fillers, pauses, and selfcorrection to convey the desired message

8. Use grammar correctly: Tenses, parts of speech, word classes (nouns, verbs, etc.)

9. Produce natural speaking: inappropriate phrases, pause groups, and breath groups.

10. Convey meaning using various grammatical forms.

11. Produce cohesive devices in speaking.

\section{Macro skills:}


12. Fulfill communicative functions in different situations for achieving goals.

13. Use appropriate styles, registers, redundancies, pragmatic conventions, and conversation rules.

14. Adopt links between situations and discourse such as events and feelings, explanations, and exemplification.

15. Make use of nonverbal cues like facial expressions, gestures, andbody language as well as verbal language.

16. Adopt a variety of speaking strategies, such as highlighting keywords, and ensuring that the interlocutor is grasping the intended message.

\section{Speaking activities:}

Learners need exposure to some aspects that can help them to speak effectively. Florez (1999, p. 3) pointed out that, learners should practice how to use correct vocabulary to describe their ideas. Moreover, learners should know how to clarify their message using appropriate facial expressions and gestures. It is so important that teachers give learners more practice on other speaking features like stress and intonation, words to clarify the description if the clerk does not understand, and use appropriate facial expressions to indicate satisfaction or dissatisfaction with the service. Other skills and knowledge that instruction might address include the following: producing the sounds, stress patterns, rhythmic structures, and intonations of the language.

Gómez (2018, pp. 86-87) identified the following speaking activities for primary school pupils: 
a) Chants and songs provide a chance for pupils to mimic models and learn stress and intonation.

b) Pair work and games provide an effective learning situation to practice spontaneous and fluent speaking.

\section{Feature of speaking tasks:}

Roca-Varela and Palacios (2013, pp. 58-61) discussed the features of speaking tasks categories by providing, where possible, specific examples of each task type:

A. Structured speaking tasks, such as giving short answers and reading loud tasks.

B. Personal interviews, the examiner usually starts with simple personal questions about name, age, likes, and dislikes to get learners familiar with the speaking test.

C. Description tasks are used to measure the learner's ability to speak continuously in response to a picture or a scene.

D. Topic discussions are used to measure learner's ability to speak fluently at a certain length on a given topic.

\section{Types of speaking tasks}

\section{Brown (2004, pp. 41-142) identified five types of speaking:}

1. Imitative. The learner imitates and repeats a word or phrase. The emphasis is mainly on the phonetic aspect of oral production but the learner also can acquire lexical and grammatical patterns of language

2. Intensive. The learner produces short stretches of oral language that shows his ability to use certain grammatical, lexical, and phonological patterns. 
3. Responsive. The learner produces certain language functions like greeting, apologizing, or thanking.

4. Interactive. The learner here produces more detailed discourse involving the exchange of information with multiple participants.

5. Extensive (monologue). Include types of speaking like speeches, presentations, and narrating a story. There is little integration with the listener.

\section{Modeling:}

According to the social learning theory of Bandura (1969, pp. 120122), all learning aspects resulting from direct experience can occur on a vicarious basis through the process of observing others' behavior. Thus, one can acquire complex skills by just observing the performance of an appropriate model. Bandura highlighted the importance of reinforcement, motivation, and the attention of observers for observational learning to take place.

Martin and Pear (2015, p. 219) identified modeling as a procedure that presents a sample of a given behavior to an individual to encourage him to produce similar behavior. But what determines whether or not we will imitate the behavior of a model? Martin and Pear's explanation is that: reinforcement and punishment are the major factors in the process of imitation.

Bandura (1969, pp. 120-130) identified the circumstances that make modeling successful in terms of procedures. In Bandura's theory of 
observational learning, the following four factors are important for learning to take place:

(a) attention to targeted behavior;

(b) retention in observer's memory;

(c) reproduction of the behavior on a suitable occasion;

(d) motivation to imitate the previously observed behavior.

\section{Modeling and language learning process:}

Modeling is very important for language learning in general. Bandura (2017, p 186) highlighted the role of imitation and modeling in the language learning process. He argued that people can learn languages through observation and modeling without the need for direct teaching giving more priority to the vicarious process of learning.

\section{Video-self-modeling:}

The use of VSM in educational and training settings has been slow in evolving. The main reason for this is technology, tools, and the skills needed to capture and edit videos. Previously, VSM, editing process was so hard as it involved transferring video from tape to tape and we had to use a lot of equipment. This explains why the use of VSM was rare outside research purposes. With the advent of modern technology, equipment, and tools make it easier for researchers and teachers to edit videos without the need for high skills in technology. New software and friendly user editing applications pave the way to larger usage of VSM intervention in many fields and for several purposes. A lot of studies applied the VSM technique for developing the required behavior or academic skills. The results of these studies explain why we should be optimistic about the potential of 
video-modeling, as the majority of studies showed good gains by study participants (Buggey\& Ogle, 2012, pp. 52-53).

Nowadays, the vast spread of smartphones makes it much easier to capture and edit video and this has a positive impact on using VSM in schools.

\section{The theoretical base for using VSM:}

According to Dowrick and Biggs (1983, pp. 105-108), the following elements provide theoretical support for using VSM:

Firstly, observational learning studies show that one can learn new skills through just imitating others. We can learn better by imitating similar models. Here, in VSM intervention the model and the observer are the same; the pupil himself. Change is enhanced by model similarity.

Secondly, research in video replay indicates that just replaying one's behavior without editing video with the same errors results in Secondly, research in video replay to enhance certain skills with the same errors and feedback has negative consequences on the process of learning. One difference between VSM and other forms of video replay is that selfmodeling shows only successful performance and eliminates errors. It concentrates on the positive side of performance. On the other hand, just replaying a video with the same actions and behaviors does not prove to be effective in acquiring new skills.

Finally, self-efficacy plays an important role in learning through modeling as we tend to perform well when we believe in our capabilities; when we see our future successful performance. 
Bellini and Akullian (2007, p. 256) in their meta-analysis study of Video Modeling and Video Self-Modeling interventions concluded that video modeling and VSM are effective intervention strategies for handling social-communication skills, functional skills, and behavioral functioning. Results also indicate that these procedures enhance skill acquisition. Skills we acquire via video-self modeling are maintained by positive reinforcement.

\section{How video self-modeling works:}

Dowrick (2012, p. 30) stated that VSM became accepted as an extreme case of model similarity; enhanced self-efficacy became a frequent "explanation" of how it worked. Recently, Self-modeling (SM) adopts unique procedures as it represents "images of oneself engaged in adaptive behavior". In this intervention oneself is observed to be successful, enhanced self-efficacy became a reasonable "explanation" of how it worked. Many factors contribute to personal learning, efficacy, and well-being. They are as follow:

- Identification of goals and outcome,

- Showing a positive self-image,

- Reminders of enhanced competence,

- repeated observation of a similar model,

- Transformation of behavior to a new setting,

- lessening level of anxiety while performing skill,

- demonstrations of new skills composed of pre-existing sub-skills.

VSM and speaking: 
Buggey and Ogle (2012. P. 64) argued that the areas of speech and language development seem a natural fit for VSM intervention. Teachers have long used mirrors to show pupils the proper mouth formations for certain sounds, and this in itself is a form of self-modeling. Through VSM intervention pupils can imitate sounds and words that they cannot utter easily. Moreover, many speaking problems like stuttering, hesitation, and speaking anxiety can be handled using VSM.

\section{Types of VSM:}

Dowrick et al, (2006, pp. 194-195) distinguish between two types of VSM: feed-forward and positive self-review.

\section{Video feed-forward:}

Dowrick et al, (2006, p. 194) argued that Video feed-forward can create images of positive futures, in this type of VSM we can teach new skills and behaviors using well-edited videos that show the future successful performance of the learner. All creatures learn from observing their successes, but not usually on video; humans distinguish themselves by their unique ability to learn through observing successes they have not yethad. This type of selfmodelingis known as feed-forward, an image of future mastery (a term coined to contrast with feedback, which illustrates past or present performance).

\section{Positive self-review:}

Positive self-review refers to "selectively compiling the bestrecorded examples of target skills already manageable but infrequently achieved" (Dowrick, 1991, p.109). In the positive self- 
review mode, one is filmed doing skills or behaviors that he or she can already achieve independently with encouragement and positive reinforcement. Successful trials are filmed and edited to show the best performance of the target skill and removing errors. The positive self-review video encourages and enhances our ability to master these skills or behaviors. Positive self-review mode has been used successfully in the field of sports. In the training of athletes, for example, trainers create videos gathering best swim strokes for review. This technique can help people to perform a seldom-achieved or recently acquired skill (Boisvert and Rao, 2015, p. 38).

\section{The intervention of the study:}

The present study applied VSM technique as a type of modeling that depends on creating short videos for slow pupils showing each one performing and speaking fluently after editing original videos and removing errors and the researcher's support. Pupils watch their videos for three weeks to gain self-efficacy and self-confidence and get motivated to speak fluently.

\section{Duration of the experiment:}

The experiment was carried out in the second term of the scholastic year 2019-2020. It started on February 8th, 2020, and ended on May 20th, 2020.

\section{VSM intervention Procedures:}

Based on recommendations of the previous studies mentioned in chapter two, the researcher applied the following procedure 
1. Arranging settings for applying the intervention.

2. Recording videos for each pupil.

3. Editing videos to create 2 short videos for pupils showing them performing and speaking well without errors or hesitations.

4. Getting pupils to watch their videos individually 3 times a week for 3 weeks.

5. Applying speaking post-test and collecting data about their speaking skills after implementing VSM.

6. Doing statistical analysis and finding out results and conclusions.

\section{Data Analysis:}

\section{The statistical techniques used in the present study:}

1. Wilcoxon matched-pairs signed-rank test.

2. Matched- Pairs Rank biserial correlation.

3. Modified Blake's Gain Ratio by the equation.

\section{Verifying hypothesis (1)}

\section{Table 1}

Wilcoxon Signed Ranks Test of the difference between the mean scores of the sample pupils on both pre and post speaking skills test 


\begin{tabular}{|c|c|c|c|c|c|c|c|c|}
\hline Skills & Signed Ranks & $\mathbf{N}$ & $\begin{array}{l}\text { Mean } \\
\text { Rank }\end{array}$ & $\begin{array}{l}\text { Sum of } \\
\text { Ranks }\end{array}$ & $\mathbf{Z}$ & Sig & $\mathbf{r}_{\mathrm{prb}}$ & $\begin{array}{c}\text { Effect } \\
\text { size }\end{array}$ \\
\hline \multirow{3}{*}{ Fluency } & $\begin{array}{l}\text { (*) Negative } \\
\text { Ranks }\end{array}$ & 0 & 0.00 & 0.00 & \multirow{3}{*}{1.841} & \multirow{3}{*}{0.066} & \multirow{3}{*}{1.00} & \multirow{3}{*}{$\begin{array}{l}\text { Very } \\
\text { strong }\end{array}$} \\
\hline & $\begin{array}{c}(* *) \text { Positive } \\
\text { Ranks }\end{array}$ & 4 & 2.50 & 10.00 & & & & \\
\hline & $(* * *)$ Ties & 0 & & & & & & \\
\hline \multirow{3}{*}{ omprehension } & Negative Ranks & 0 & 0.00 & 0.00 & \multirow{3}{*}{1.841} & \multirow{3}{*}{0.066} & \multirow{3}{*}{1.00} & \multirow{3}{*}{$\begin{array}{l}\text { Very } \\
\text { strong }\end{array}$} \\
\hline & Positive Ranks & 4 & 2.50 & 10.00 & & & & \\
\hline & Ties & 0 & & & & & & \\
\hline \multirow{3}{*}{ Nonverbal } & Negative Ranks & 0 & 0.00 & 0.00 & \multirow{3}{*}{1.826} & \multirow{3}{*}{0.068} & \multirow{3}{*}{1.00} & \multirow{3}{*}{$\begin{array}{c}\text { Very } \\
\text { strong }\end{array}$} \\
\hline & Positive Ranks & 4 & 2.50 & 10.00 & & & & \\
\hline & Ties & 0 & & & & & & \\
\hline \multirow{3}{*}{ Grammar } & Negative Ranks & 0 & 0.00 & 0.00 & \multirow{3}{*}{1.841} & \multirow{3}{*}{0.066} & \multirow{3}{*}{1.00} & \multirow{3}{*}{$\begin{array}{l}\text { Very } \\
\text { strong }\end{array}$} \\
\hline & Positive Ranks & 4 & 2.50 & 10.00 & & & & \\
\hline & Ties & 0 & & & & & & \\
\hline \multirow{2}{*}{ Pronunciation } & Negative Ranks & 0 & 0.00 & 0.00 & \multirow{2}{*}{1.857} & \multirow{2}{*}{0.063} & \multirow{2}{*}{1.00} & \multirow{2}{*}{$\begin{array}{c}\text { Very } \\
\text { strong }\end{array}$} \\
\hline & Positive Ranks & 4 & 2.50 & 10.00 & & & & \\
\hline
\end{tabular}

Negative Ranks : Post test< Pre test $\left({ }^{*}\right)$

Positive Ranks: Post test> Pre test (**)

Ties: Post test $=$ Pre test $(* * *)$ 


\begin{tabular}{||c|c|c|c|c|c|c|c|c|}
\hline & Ties & 0 & & & & & & \\
\hline \multirow{5}{*}{ Vocabulary } & Negative Ranks & 0 & 0.00 & 0.00 & & & & \\
\cline { 2 - 6 } & Positive Ranks & 4 & 2.50 & 10.00 & 1.826 & 0.068 & 1.00 & $\begin{array}{c}\text { Very } \\
\text { strong }\end{array}$ \\
\cline { 2 - 8 } & Ties & 0 & & & & & & \\
\hline
\end{tabular}

As shown in the above table, there were no statistically significant differences at the 0.05 level between the mean ranks scores of the sample pupils' pre and post speaking skills test regarding sub-skills. The statistical investigation led to the rejection of hypothesis (1)

The results of matched- pairs rank biserial correlation (rprb)value is 1 that indicates a large effect size and strong correlation between the study intervention (VSM) and the development of all speaking sub-skills test of the study sample. This development did not show a statistically significant difference in Wilcoxon test because of the short sample number (four pupils).

\section{Table 2:}

Modified Blake's Gain Ratio in speaking sub-skills test of the study sample

\begin{tabular}{||c|c|c|c|c||}
\hline SKill & Pre & Post & Full & Modified Blake's Gain \\
& Mean & Mean & Mark & Ratio \\
\hline
\end{tabular}




\begin{tabular}{||l|c|c|c|c||}
\hline Fluency & 0.75 & 3.00 & 4.00 & 1.25 \\
\hline omprehension & 0.50 & 3.25 & 4.00 & 1.47 \\
\hline Nonverbal & 0.50 & 3.00 & 4.00 & 1.34 \\
\hline Grammar & 0.25 & 3.25 & 4.00 & 1.55 \\
\hline Pronunciation & 2.63 & 7.00 & 8.00 & 1.36 \\
\hline Vocabulary & 3.5 & 6.00 & 6.00 & 1.42 \\
\hline
\end{tabular}

As shown in the above table, Modified Blake's Gain Ratio value is bigger than 1.2 in all speaking sub-skills which means that the VSM intervention is accepted and satisfying. VSM proved to have a large effect on developing the target skills.

The following chart (figure 2) shows the difference between the mean scores of the study sample in pre and post-speaking test regarding speaking sub-skills 
عنو ان المخطط

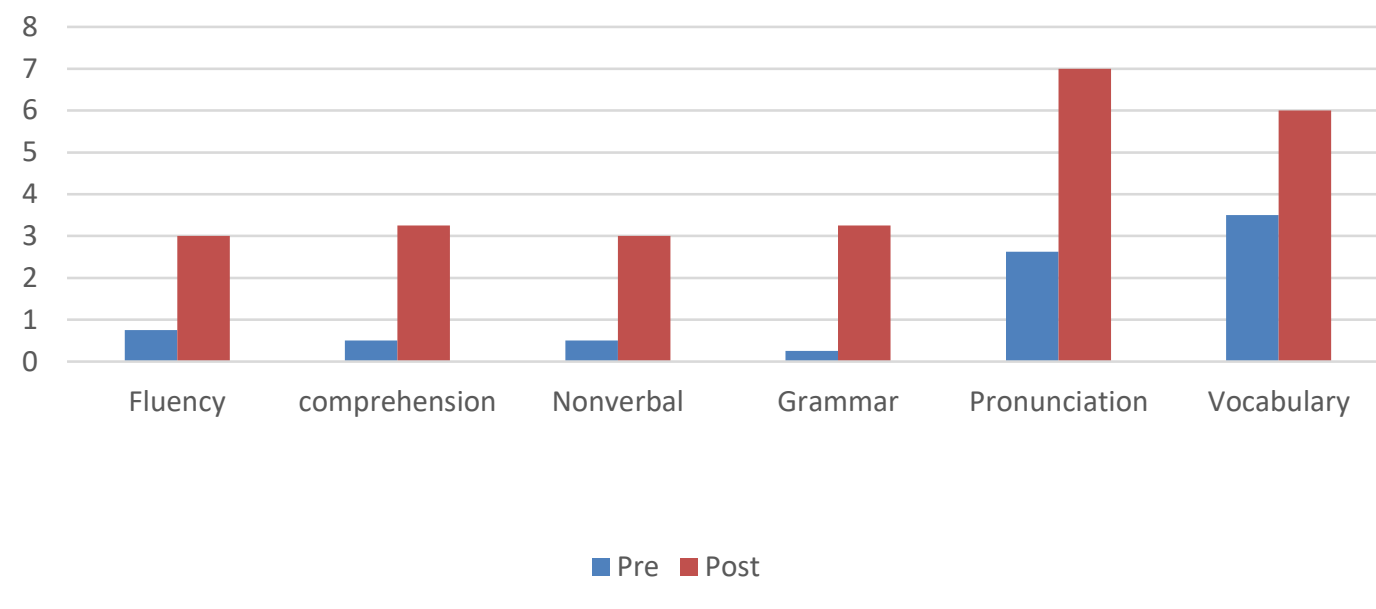

\section{Figure 2:}

As shown in figure 2 there was remarkable increased development in all speaking sub-skills of the study group after applying the VSM intervention.

Verifying hypothesis (2) 


\section{Table 3}

Wilcoxon Signed Ranks Test of the difference between the mean scores of the sample pupils on both pre and post overall speaking test

\begin{tabular}{|c|c|c|c|c|c|c|c|c|}
\hline Skills & $\begin{array}{l}\text { Signed } \\
\text { Ranks }\end{array}$ & $\mathbf{N}$ & $\begin{array}{l}\text { Mean } \\
\text { Rank }\end{array}$ & $\begin{array}{c}\begin{array}{c}\text { Sum } \\
\text { of } \\
\text { Ranks }\end{array} \\
\end{array}$ & $\mathbf{Z}$ & Sig & $\mathbf{r}_{\mathrm{prb}}$ & Effectsize \\
\hline \multirow{3}{*}{$\begin{array}{c}\text { All Over the } \\
\text { test }\end{array}$} & $\begin{array}{c}\left(^{*}\right) \\
\text { Negative } \\
\text { Ranks }\end{array}$ & 0 & 0.00 & 0.00 & \multirow{3}{*}{1.826} & \multirow{3}{*}{0.068} & \multirow{3}{*}{1.00} & \multirow{3}{*}{ largeeffect } \\
\hline & $\begin{array}{c}\left({ }^{* *}\right) \\
\text { Positive } \\
\text { Ranks }\end{array}$ & 4 & 2.50 & 10.00 & & & & \\
\hline & $\begin{array}{l}\left({ }^{* *}\right) \\
\text { Ties }\end{array}$ & 0 & & & & & & \\
\hline
\end{tabular}

As shown in the above table there were no statistically significant differences at the 0.05 level between the mean ranks scores of the sample pupils' pre and post speaking skills test regarding the overall test. The result led to the rejection of the study second hypothesis

Matched- Pairs Rank biserial correlation ( $\left.\mathbf{r}_{\text {prb}}\right)$ values equal (1) indicating a large effect size and strong correlation between the study intervention (VSM) and the mean scores of the study sample in the

$$
\begin{array}{r}
\text { Negative Ranks : Post test< Pre test }(*) \\
\text { Positive Ranks: Post test }>\text { Pre test }\left(*^{*}\right) \\
\text { Ties: Post test }=\text { Pre test }\left(*^{*} *\right)
\end{array}
$$


overallspeaking skills post-test, This development did not show a statistically significant difference in Wilcoxon test because of the short sample number (four pupils).

\section{Table 4}

Modified Blake's Gain Ratio in the overall speaking test of the study

\begin{tabular}{|c|c|c|c|c|}
\hline \multirow{2}{*}{ SKill } & Pre & Post & Full & Modified Blake's \\
& Mean & Mean & Mark & Gain Ratio \\
\hline All over the test & 8.13 & 25.5 & 30 & 1.37 \\
\hline
\end{tabular}

As shown in the above table, the Modified Blake's Gain Ratio value is bigger than 1.2 in the overall speaking skills test indicating that the VSM intervention is accepted and satisfying and very effective in developing the study sample speaking skills. The study intervention proved to have a large effect on developing the study sample performance in the overall speaking test.

The following chart shows the difference between the mean scores of the study sample in pre and post overall the speaking test result 


\section{عنو ان المخطط}

30

25

20

15

10

5

0

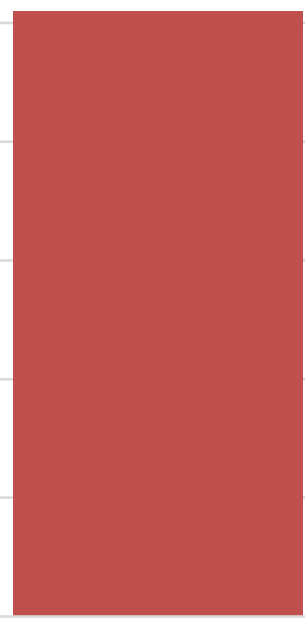

All Over The Test

- Pre Test $\quad$ Post Test

\section{Figure 3:}

As shown in the above chart there is a significant difference between pre and post-test performance in favor of the study sample indicating VSM intervention as a suitable technique for developing speaking skills.

\section{Results and discussion:}

The statistical analysis indicated that VSM intervention could be effective in developing speaking skills. The pupils of the study sample showed improved performance in the overall post-test and every sub-skill. Moreover, VSM proved to be a positive intervention as the pupils of the study sample expressed their satisfaction and happiness watching their successful performance. These results answer research question three that 
sought to investigate the effect of VSM on developing speaking skills. This could be due to the following reasons:

First, the present study applied an evidence-based intervention that showed great success in developing pupils' behavior and linguistic skills such as reading and speaking as presented in previous studies.

Second, pupils in this intervention are so interactive and representing the model and the observer at the time as it depends on watching oneself successful experience of speaking fluently.

Third, this intervention is a positive technique that focuses on success and focuses on the targeted skills that enhance pupil's self-confidence and self-efficacy. This increased pupils' sense of their capabilities and pushed them to acquire the desired skills

Fourth, this intervention handles speaking and communication problems like anxiety, shyness, and hesitations as it shows pupils best performance that leads to overcoming common communication problem

Finally, VSM aroused pupils' motivation and their desire to achieve better as a result of seeing themselves in their edited videos as wonderful models.

A remarkable finding of this study is that primary pupils memorize much of textbooks vocabulary but they cannot utter a simple sentence and cannot take part in simple conversation. One reason for this is the fact that speaking is something beyond words and structure, it involves verbal and nonverbal skills as well as comprehension and interaction between speakers, skills. These elements are missing in our classrooms and can be 
handled by applying VSM intervention and can lead to great progress in pupils' ability to speak and communicate effectively.

The findings of the present study are consistent with several prior studies that proved the effectiveness of VSM in developing speaking skills such as the studies of Buggey (1995), Bray and Kehle(1996),Buggey (2005), Buggey and Ogle (2012), Sen (2016), and Andrade (2018).

There are not many studies in related literature applying VSM intervention with speaking skills so we hope that this study can fulfill that gap in the literatureand enhances speaking using the promising features of VSM.

\section{Conclusions}

Based on the findings of the study, it can be concluded that VSM is an effective intervention in developing the speaking skills of primary school pupils, as it entails the following advantages:

1. There is evidence that the use of VSM attributed to enhancing all targeted speaking sub-skills of the study sample

2. there is evidence that VSM intervention can be used in our schools by class teachers with little training on procedures and editing software.

3. VSM proved to be an effective intervention in improving speaking fluency and nonverbal skills because of the nature of this intervention in concentrating on showing future performance of pupils and showing them as good models to be followed and observed 
4. VSM is an intervention of success and fulfillment that attribute in encreasing pupils self-efficacy that enhances positive attitude toward speaking fluently and learning a language in general

5. With the advent of modern technology of camcorders, editing software and smartphone VSM represent a considerable savings of time and effort for teachers, therapists, and job coaches. ( Buggey and Ogle, 2012, p. 67)

6. The result seems to indicate that slow pupils need more care from their teachers and skate holder and this intervention proved to be a proper solution handling this problem as it shows the pupil as a hero or a star appearing in a unique video of him speaking the target language fluently.

\section{Recommendations:}

Based on the findings, the following recommendations are made:

1. Speaking skills of primary pupils need to be enhanced through alternative techniques like VSM to make use of their effect in improving overall speaking skills

2. Concentrating only on vocabulary and grammar does not helppupils to make progress in speaking skills so classroom teachers need to involve other efficient techniques like VSM that enhances studentcentered learning and active learning

3. Training teacher on applying VSM and providing them with proper equipment to ease their use of this effective intervention in handling speaking problems like shyness anxiety and hesitations 
4. We should give more priority to speaking skills and involve speaking in assessment tests and allocate proper time and effort for mastering communication skills.

\section{Suggestions for Further Research:}

Listed below are some suggestions for further research

- The use of VSM to develop slow pupils' listening skills.

- Using VSM to improve primary school pupils' communication skills.

- Using VSM with preschool children to develop their speaking skills as they like to imitate cartoon and similar models.

- Using VSM to develop public speaking skills for preparatory stage students.

- Using VSM to develop debate skills for secondary stage students.

\section{References}

Andrade, B. K. (2018). Using video self-modeling to increase social communication in children with autism spectrum disorder. Retrievedfrom:https://opencommons.uconn.edu/cgi/viewcontent.c gi? article $=7976 \&$ context $=$ dissertations

Bandura, A. (1969).Principles of behavior modification.Holt, Rinehart and Winston, INC. New York

Bandura, A. (Ed.). (2017). Psychological modeling: Conflicting theories. Transaction Publishers. Retrieved from: 
https://books.google.com.eg/books?id=skDR5dX6gyAC\&printsec $=$ frontcover $\& \mathrm{dq}=\% \mathrm{E} 2 \% 80 \% \mathrm{~A} 2 \% 09 \mathrm{Bandura},+$ Social+learning $+\mathrm{la}$ nguage \&hl=en\&sa=X\&ved=0ahUKEwi33Jjs5d3pAhUK8hQKHd YoAm8Q6AEIQjAD\#v=onepage $\& \mathrm{q}=$ language $\& \mathrm{f}=$ false

Borah, R. R. (2013). Slow learners: Role of teachers and guardians in honing their hidden skills. International Journal of Educational Planning \& Administration, 3(2), 139-143.

Bray, M. A., \&Kehle, T. J. (1998).Self-modeling as an intervention for stuttering. School Psychology Review, 27(4), 587. Retrieved from: https://search.proquest.com/openview/249c05700da487e1a7f174f $81 \mathrm{fd} 58115 / 1$ ?pq-origsite $=$ gscholar \&cbl $=48217$

Brown, H. D. (2004).Language assessment. Principles and Classroom Practices. San Francisco, California: Longman.

Buggey, T. (1995). An examination of the effectiveness of videotaped self-modeling in teaching specific linguistic structures to preschoolers. Topics in early childhood special education, 15(4), 434-458.Retrieved

from: http://citeseerx.ist.psu.edu/viewdoc/download?doi=10.1.1.941.837 $4 \&$ rep $=$ rep $1 \&$ type $=$ pdf

Buggey, T. (2005). Video self-modeling applications with students with autism spectrum disorder in a small private school setting. Focus on autism and other developmental disabilities, 20(1), 52-63. Retrieved from:

https://journals.sagepub.com/doi/pdf/10.1177/1088357605020001 0501 
Buggey, T., \& Ogle, L. (2012).Video self-modeling. Psychology in the Schools, 49(1), 52-70. Retrieved from: https://onlinelibrary.wiley.com/doi/full/10.1002/pits.20618

Chappel, S. (2008).Video Modeling and Video Self-Modeling. Retrieved from:

http://166.67.65.131/documents/CoPAminutesValley20090701 VideoSelfModeling.pdf

Cranmer, G. A. (2017). One-group pretest-posttest design.In The SAGE Encyclopedia of Communication Research Methods.edited by M Allen, SAGE Publications, Inc, Thousand Oaks, CA, pp, 11251126. Retrieved from: https://cutt.ly/7uFjytk

Diyyab, E. A. (2014).Using a multimedia-based program for developing student teachers' EFL speaking fluency skills. Retrieved from ERIC database. (ED 539987).

Dowrick, P. W., \& Biggs, S. J. (1983).Using video: Psychological and social applications.John Wiley \& Sons Inc. New York

Dowrick, P. W. (1999).A review of self modeling and related interventions. Applied and preventive psychology, 8(1), 23-39.

Dowrick, P. W., Kim-Rupnow, W. S., \& Power, T. J. (2006). Video feedforward for reading. The Journal of Special Education, 39(4), 194-207. Retrieved from: journals.sagepub.com/doi/pdf/10.1177/00224669060390040101

Dowrick, P. W. (2012). Self modeling: Expanding the theories of learning. Psychology in the Schools, 49(1), 30-41. Retrieved from: https://doi.org/10.1002/pits.20613 
El-Bassuony, J. M. E. B. (2010). The role of Readers Theatre in Developing Speaking Skills and Reducing Speaking Anxiety of EFL Secondary School Students (An experimental study)Faculty of Education Magazine, Port Said University. 8(8), 57-107.

Florez, M. C. (1999).Improving Adult English Language Learners' Speaking Skills. ERIC Digest. Retrieved from: ERIC database. (ED435204)

Gómez, A.M. (2018).English language teaching in primary schools.Handbook for Castilla La Mancha. Albacete. The Internet Archive

Iswara, A. A., Azib, A., \&Rochsantiningsih, D. (2012).Improving students' speaking fluency through the implementation of triviabased activity in university students. Retrieved from: https://media.neliti.com/media/publications/60183-EN-improvingstudents-speaking-fluency-thro.pdf

Kaminskiene, L., \&Kavaliauskiene, G. (2014).Attitudes to Improving Speaking Skills by Guided Individual Activities. Coactivity: Philology, Educology/Santalka: Filologija, Edukologija, 22(1), 3948.

Martin, G., \& Pear, J. J. (2015). Behavior modification: What it is and how to do it. Psychology Press. Retrieved from: https://cutt.ly/fuFlVXj

Mary, S., Alan, P., \& Melanie, W. (2005). The TKT: Teaching Knowledge Test Course. Cambridge: Cambridge University Press. Retrieved from: https://cutt.ly/3uFzuuW 
Mcllwraith, H., \& Fortune, A. (2016).English language teaching and learning in Egypt: an insight. London: British Council

Nazara, S. (2011).Students' perception on EFL speaking skill development. JET (Journal of English Teaching), 1(1), 28-43.

Rizvi, M. A. (2005). Effective Technical Communication: 2/e. McGrawHill Education. Retrieved from: https://cutt.ly/1uFzbUJ

Segura Alonso, R. (2012). The importance of teaching listening and speaking skills. Madrid: The Complutense University of Madrid. Retrieved from:https://www.ucm.es/data/cont/docs/119-2015-0317-12.RocioSeguraAlonso2013.pdf

Sen, Ü. (2016).Video Self-Modeling Technique That Can Be Used in Improving the Abilities of Fluent Reading and Fluent Speaking. International Education Studies, 9(11), 66-75. Retrieved from: https://files.eric.ed.gov/fulltext/EJ1118581.pdf

Shmavonyan, G., \&Karapetyan, L. (2017).DEALING WITH SLOW LEARNERS IN THE LANGUAGE CLASS. Retrieved from: http://ysu.am/files/DEALING-WITH-SLOW-LEARNERS.pdf

ŠOLCOVÁ, P. (2012). Teaching speaking skills (Doctoral dissertation, Masaryk University, Faculty of Arts

Thyer, B. A. (2012). Quasi-experimental research designs. Oxford University Press.Retrieved from: https://cutt.ly/xuFz36b

Torky, S. A. E. (2006).The Effectiveness of a Task-Based Instruction Program in Developing the English Language Speaking Skills of Secondary Stage Students. Retrieved from: https://eric.ed.gov/?id=ED523922 
Zhang, Y. (2009). Reading to Speak: Integrating Oral Communication Skills.

In English Teaching Forum, 47(1), 32-34. Retrieved from Eric: https://files.eric.ed.gov/fulltext/EJ923446.pdf 